\title{
Discussion on Interactive Mechanism of Law Education of Undergraduate Course and Vocational Education of Law
}

\author{
Xuan Gao \\ Law School \& Intellectual Property School \\ Jinan University \\ Guangzhou, China 510632
}

\begin{abstract}
The law education of undergraduate course is the education that students of law schools absorb basic knowledge of law and train basic professional skills. It has little relationship with vocational education of law. So a large number of graduates of law cannot meet the requirements of social position. The practical teaching level and the quality of talents cultivation cannot get substantial progress. Under the background of building the professional community of the law and improving national unified system of professional qualifications of law, the building of interactive mechanism of them should become important task of the current teaching reform of law. The interactive mechanism of law education of undergraduate course and vocational education of law can improve the teaching system of law education of undergraduate course, improve the undergraduate teaching quality and let the graduates of law have basic professional quality required by practical departments.
\end{abstract}

Keywords-law education of undergraduate course; vocational education of law; teaching reform; interactive mechanism

\section{INTRODUCTION}

In 2011, the Ministry of Education and the Committee of Political and Legislative Affairs jointly issued the Several Opinions on Implementing the Education Plan of Excellent Legal Talent and pointed out "the emphasis of implementing the education plan of excellent legal talent is to train applied and compound type talents of legal profession. In 2014, the Resolution on Certain Major Issues Concerning Comprehensively Advancing the Law-based Governance of China on the Communique of the Fourth Plenary Session of the 18th Central Committee of the Communist Party of China mentioned "improving the two-way communication mechanism of political-legal department and personnel of law schools and research institution of law". In 2016, the Opinions on Improving National Unified System of Professional Qualifications of Law issued by the General Office of the CPC Central Committee and the General Office of the State Council define the conditions of legal professional qualification and the professional threshold is improved. From the perspective of official documents on legal construction and improving the quality of talents of the legal profession in recent years, the

*The article is one of the achievements of the education reform project of Guangdong province in 2013, "Research on Case Teaching Reform in Personnel Training Mode of Application-oriented Law Major Undergraduate" (Project No. 51052246). law education of undergraduate course undertakes more training tasks. The teaching reform of law will step forward in step-by-step plan.

The interaction between the law education of undergraduate course and the vocational education of law is the operation of interplay. They provide active elements for each other and form composition of forces for law education. The interaction mechanism is that they join up and present the open living state of law education. However, in most Chinese universities, the law education focuses on classroom instruction. The traditional teaching mode occupies the main position. The vocational education of law is in the secondary position of classroom education of universities. It even gains no attention. The vocational education of law is not valued, which directly breaks the links with the law education of undergraduate course and forms tension action with the law education of undergraduate course.

The law education of undergraduate course is the elementary stage for law students to receive knowledge of law education. Although at present, the educational circles have different positioning of quality-oriented education, elite education, liberal education and vocational education, it cannot be denied that the law education of undergraduate course is basic education and the law is a disciplinary emphasizing application. The undergraduates of the law major (hereinafter referred to as "law undergraduates") mainly learn basic professional disciplines during university and basically grasp legal theory and form certain legal thinking. However, the understanding of many law undergraduates on subject-based questions is superficial. Besides, because of being influenced by many reasons that the traditional teaching focuses on teaching, values knowledge more than proficiency, with uneven teaching resources and less skill training, the law undergraduates show inadequate ability of active study and practical ability and legal thinking. The law education of undergraduate course lacks the idea of caring for practical skill and ability. It makes the theoretical capacity and the application ability of law undergraduates develop unevenly. Meanwhile, it is difficult for law undergraduates to meet basic requirements of post of duty after graduation. 
Nowadays, the interactivity between the law education of undergraduate course and the vocational education of law is insufficient. The reasons are as follows: (1) The positioning and the object of law education are unclear. The development process of the law education in contemporary China is full of twists and turns. Different periods have different positioning and objects. The country explains the overall object of the law education. At present, universities of professional building of law have different types and levels, including research-based, research type with industry characteristics, applicationoriented, research type with regional characteristics; top university, first-class university, high-level university, wellknown university and ordinary university. Different natures of universities decide the specificity of teaching objectives of law education. The patterns of running schools and levels of law school in universities differ in thousands of ways. The acceptance of national unified objects is barely satisfactory. They need to base on reality to make response and correctly select the objects of law education. [1] The competition of the positioning of quality-oriented education, elite education, liberal education and vocational education will disturb the training direction of law undergraduates. Each positioning is reasonable, but just as the teaching objectives of law education, it should combine with practice. It should be different types of combination for law education. If we only emphasize qualityoriented education, liberal education or professional education and elite education, it goes against the interaction between the law education of undergraduate course and the vocational education of law. The professional development foundation of law undergraduates will lack diversity. It is difficult for them to meet the requirements of the post of duty with single professional ability. (2) The law education of undergraduate course and the vocational education of law are different. The law education of undergraduate course is the learning pattern of classroom teaching and attaches importance to the teaching of professional theory of law undergraduates; the vocational education of law bases on training practical ability of students or common professional examination or paying attention to training practical thinking and ability of students with rich training modes. The world is wonderful because of the complexity and differences of things. The contradiction of things is unity of opposites. We need to seek a balance between different things and exert the initiative of things. Because the vocational education of law pays more attention to professional qualification examination, building interactive mechanism between the law education of undergraduate course and the vocational education of law may lead to the situation that the law education of undergraduate course becomes exam-oriented education. Law undergraduates will become the machine of exam and cannot grasp theoretical knowledge of the specialty. In addition, the law education of undergraduate course is deeply influenced by traditional teaching mode and most law undergraduates receive knowledge passively and answer the questioning of teachers negatively, showing inert learning state. In this way, teachers are inclined to repeat what the book says. Because the traditional teaching method of the law education of undergraduate course is conservative, the vocational education of law cannot enter the classroom of law education. It becomes "long-standing" about how to scientifically design the interactive platform of the law education of undergraduate course and the vocational education of law. (3) The teaching level of different universities are different. The number of university in our country that opens the law major has reached more than 600. Each year, plenty of graduates of law enter the society. Compared with the supply and demand status of graduates of law in the past, at present, it appears the phenomenon that the supply exceeds demand. The distribution of teaching resources in different places of our country is unbalanced because of different reasons. Some universities enjoy advantaged teaching resources. The teaching resources of some universities are insufficient and cannot enjoy the support of policies. The unbalance of teaching resources of universities is the external reason of different teaching levels of universities. For this reason, universities lack of teaching resources put too little or no energy in the vocational education of law. Under the situation that the quality of the law education of undergraduate course cannot be guaranteed, the level of the law education hovers at low level. Besides, the different teaching level of universities means universities with low level do not have natural resource superiority and regional advantages in getting training resources. There are few practice bases. The practice outside the classroom of law undergraduates is single. In this way, these universities will transfer the cost to traditional classroom teaching or give up the construction of the practice course.

The vocational education of law is to teach knowledge and skills required by the law undergraduates to take up the legal profession. It can urge law undergraduates to transfer the theoretical knowledge into practical application. Our country has improved the national unified system of professional qualification of law. The importance of the vocational education of law has spoken for itself. The teaching reform of deepening law education is imperative. Law students should learn law theory at the same time exercise legal thinking and professional quality, which depend on the vocational education of law. In general, the vocational education of law is indispensable for the formation of professional thinking and literacy of law students.

\section{MEASURES TO BUILD INTERACTIVE MECHANISM OF THE LAW EDUCATION OF UNDERGRADUATE COURSE AND THE VOCATIONAL EDUCATION OF LAW}

The law education of undergraduate course undertakes the basic, systematic and comprehensive teaching tasks of law for law students. It can let them deepen the learning of the legal profession and connect the knowledge with the work, which is the trend of teaching. Excellent legal talents should have corresponding legal thinking and legal skills. The legal thinking is the advanced stage that guides a person to finish activities of case analysis and know the law. The formation of professional thinking depends on the infusion of professional knowledge and the supply of practice exercise. The law skill is the indicator to reflect the level of practical ability of a person. Its formation relies on the degree of practice exercise. But it also needs theoretical basis to transform into practical ability. The formation of legal thinking and law skills is the result of interaction of theoretical knowledge and practice course. Therefore, realizing the effective allocation and integration of 
theoretical courses and practice courses is a way to build interactive mechanism of the law education of undergraduate course and the vocation education of law.

\section{A. Improve the Course System and Properly Increase the Proportion of Credits of Practice Courses}

In order to obtain interaction between the law education of undergraduate course and the vocational education of law, first of all, we should improve the course system and highlight the status of the vocational education of law in course system as well as let teachers and law students pay attention to the practice courses. Course system is the main carrier to train talents. It is the organism formed by courses of mutual independence and interrelation. The course system of law education should meet the training objectives integrating theoretical knowledge and practical knowledge and embody the effectiveness and stability of knowledge and information received by law undergraduates. It should let law students apply what they have learnt to the future vocational development and play a role in the career in the long run. At present, the "pragmatism" of legal learning has insufficient inclination to the existing course system. The law major should highlight the cultivation of the professional ability of law in formulating teaching scheme. [2] The course system of the law education of undergraduate course mainly includes core courses and specific provisions of department law. Both of them are compulsory courses. It should be pointed out here that the undergraduate course system of law mainly includes course teaching of theoretical knowledge and compulsory course. The theoretical knowledge course, the practice course, the compulsory course, the limited optional courses and optional subjects (or compulsory courses, elective courses) are mostly absent. Law school/department with poor qualified teachers and teaching resources are more inclined to follow this way. The course system is not logical and systematic. The improvement of course system needs to meet the realization of training objectives of law undergraduates and let them comprehensively and systematically grasp knowledge of professional field, which should play a role in the vocational development after graduation.

At present, the improvement of course system of the undergraduates of law mainly rests on the determination of proportion of courses. Undoubtedly, most courses belong to the teaching of theoretical knowledge. The key problems include how to determine the credits of practical course and practical training and whether we should increase the proportion. In order to realize the interaction of the law education of undergraduate course and the vocational education of law, realizing the effective allocation of courses is the basic project. We must increase the credits of practical teaching to improve the practical ability of law undergraduates and let them apply legal knowledge to the society. Several Opinions on Implementing the Education Plan of Excellent Legal Talent mentions the opinion that "increases the proportion of practical teaching and ensures the accumulative credit (credit hours) of the practice of law is no fewer than $15 \%$ of the total number". It is for universities to carry out the plan of training excellent legal talents. Many law schools of universities rarely take practical courses into consideration on the design of course system. Some even occupy the proportion of fewer than $10 \%$. In consideration of the unbalanced teaching resources, we can adopt diversified teaching methods to improve course system and increase credits of practical courses. For example, we can introduce such methods as case teaching, clinic type teaching, legal negotiation and seminar in course teaching. Except for compulsory courses, we can choose the course of case teaching of department law as elective courses. In this way, we can guide law undergraduates to select according to learning interests and career planning and reduce the pressure brought by insufficient teaching resources. In addition, to encourage law undergraduates to learn independently and consciously cultivate themselves into graduates of law with theoretical knowledge and practical ability, the course system can include practical and innovative project courses that students can complete independently under the guidance of teachers. The acquired results can be a part of the course credit. In a word, the setting of course system of law undergraduates should get rid of the old way of laying particular stress on theoretical courses, let the cultivation of practical ability run through the whole course system and properly increase the proportion of credits of practical courses as well as realize the organic unification of classroom teaching and extracurricular teaching.

\section{B. Make the Best of Teaching Resources, Integrate Practice with Theory}

In practice, it is difficult to realize equal distribution of teaching resources. The gap of the strength in running school of regular higher educational institutions in different areas also decides the teaching "adjusts measures to local conditions and right time". Especially when universities cannot enrich teaching methods in a short period of time, we should make the best of the existing teaching resources and combine the law education of undergraduate course and the vocational education of law. Specialized course is important content of teaching resources. Even though practical training can serve as teaching form of the vocational education of law, specialized course can be introduced in the vocational education of law. At present, the undergraduate teaching courses of law mainly include 16 core courses specified by the Ministry of Education. The core courses are theoretical and occupy more credits. Taking the function of these courses as teaching of theoretical knowledge conforms to the nature of the course. Except for these courses, the law school also open courses such as application of eloquence, legal document writing, Chinese legal system and legal logic. The professional knowledge of them is not so theoretical. Instead, it pays more attention to urging law undergraduates to learn how to use "law language" and legal thinking to analyze problems. However, in reality, some of the courses still cannot get rid of the teaching of theoretical courses. What's more, the present contents and question types of judicial examination emphasize theoretical courses and objective questions, which do not draw attention of law undergraduates. With the improvement of the national unified system of professional qualifications of law, the judicial examination is changed into professional qualification examination of law. The professional qualification examination of law major will pay attention to examining professional thinking and the concept of professional ethics. 
Compared with that of the former years, the syllabus of the national judicial examination in 2016 defines that the subjective questions will test subjects related to judicial system and legal ethics. We can definitely realize it strengthen the vocational education of law. Therefore, on the basis of the existing teaching courses, introducing the vocational education of law in courses except for the core courses and placing practice on theory helps to enrich teaching system of law education and integrate basic theoretical teaching with basic vocational teaching; helps to make use of advantages of various courses and promote the functional complementation of course resources; helps to guide law undergraduates to intensify the learning of courses except for main courses and have proper ability of taking examinations.

The vocational education of law for law undergraduates helps them to form preliminary legal professional ability after graduation and adapt to the requirements of posts of legal profession as soon as possible, reduce dual pressure of entering a higher school and employment. It cannot be understood as teaching contents on professional qualification examination of law. When making use of teaching resources, teachers should not teach simply to cater to the testing contents of professional qualification examination of law. Take the courses of the application of eloquence and Chinese legal system as examples. The application of eloquence is to train law undergraduates to use professional language and thinking to analyze mentally. Under the circumstance that the professional qualification examination of law in the future adds the link of interview, except for taking theoretical knowledge of language foundation, the course of application of eloquence can teach through many forms and let law undergraduates understand speaking skills under professional language. Chinese legal system mainly lets law undergraduates understand judicial system of China and legal liability and professional ethics of judicial professional personnel. This course greatly helps law undergraduates to perceive the professional community of law and promote the construction of the professional community of the law on working concept of graduates of law. That is to say, the teaching methods of these courses should teach practical knowledge and combine with the main theoretical courses. In a word, when carrying out the vocational education of law, use courses except for the main courses to strengthen the vocational education of law, list these courses as key courses of the vocational education of law. We should "integrate practice with theory" instead of blindly adapt to the situation of teaching reform of legal education, namely "integrate examination with teaching".

\section{Build Practice Base and Supervisory System of Practice}

Practice base is important places for law undergraduates to practice outside school as well as platform for them to present classroom knowledge. The construction of practice base should follow definite standard. According to the present teaching reform of law education, the construction of practice base should conform to the standard of being convenient for practical learning, full exercise and the balance of supply and demand. Being convenient for practical learning means the practice base should not be far away from the school. Qualified practice bases can give some subsidies to intern students, such as meal at the canteen of the practice base. Full exercise means the work task provided by the practice base should correspond to the major. Tasks that have no relationship with the major should not be given to the intern. The balance of supply and demand means the number of jobs provided by the practice base and the quantity of intern that it can accept should be balanced, to avoid that the intern purely "do odds and ends" at the practice base. These construction standards are made according to practical situation of the practice at present. Nowadays, most practice bases for law undergraduates do not play a substantial role in the vocational education of law. The potential effectiveness is not excavated fully. The essential concept to construct practice base is to list practice bases as a part of courses of vocational education of law. Through actual exercise in practice bases, law undergraduates can learn the understanding of the group of legal profession and know skills and professional quality required by legal profession under the guidance of teachers and self-learning. Furthermore, the construction of practice base also relies on the effective communication between universities and practice bases. Before building practice bases, the law school of university had better have the system of building practice base, including scheme to build practice base, agreement with practice base, construction pattern, distribution and analysis of practice bases. The selection of practice bases should break the form of "the court and law office". The practice bases of law undergraduates should be abundant and various. Especially under the background of comprehensively promoting the lawbased governance, units related to law can serve as practice bases. In practice, most practice bases are courts and law offices. Maybe students can learn more practical knowledge in courts and law offices, but personnel in units such as the procuratorate, public security organ, legal aid institution and legal departments of enterprises also belong to the community of legal profession. Enlarging forms of practice bases of law undergraduates can train their cognition for the construction of community of legal profession. Besides, law undergraduates of universities with characteristics choose units corresponding to its school-running characteristics. It helps to cultivate compound type law undergraduates and lay foundation for vocational development in the future. For example, law school of petrochemical industry universities can choose to reach an agreement of practice base with departments of environment and energy resources; law school of financial institutions can reach agreement of practice base with units such as accounting firm and banks.

Because practice bases are units outside school, law undergraduates have left the campus and have broken away from strict management of teachers in class. Almost all law undergraduates are senior high school students enrolled through college entrance examination. They lack selfdiscipline ability to some extent. Long-term learning of theoretical knowledge in class lets them lack the ability of learning knowledge of legal profession in the practice process. Besides, in practice, the phenomenon that appears most is that in order to avoid practice, some students give false information that they prepare for the postgraduate entrance exams to shorten the practice time (the practice in the seventh semester. Some universities allow candidates to apply for shortening the practice time). In addition, after the completion of practice, 
universities often ask the interns to submit the practice report, but the practice reports are often written just exactly the same as the completion method of course paper. They copy and submit it to the school. In this way, the function of practice base reduces greatly. It impedes the interaction between the law education of undergraduate course and the vocational education of law. Therefore, when building practice bases, we should also build supervisory system of practice. The supervisory system of practice is to ensure the quality of practice of law undergraduates as well as the way that teachers strengthen the vocational education of law through information reflected by the system.

\section{CONCLUSION}

It is necessary to deepen the present teaching reform of law and build interactive mechanism of the law education of undergraduate course and the vocational education of law. Some graduates of law have theoretical knowledge but they do not know how to apply. It reflects the law education lacks practical ideas of the law major. The traditional teaching methods and plan have been unable to meet the increasing requirements of working post in society for practical legal talents. The law education of undergraduate course and the vocational education of law are interactive and connected. The vocational education of law helps to improve the situation that the law education of undergraduate course attaches less importance to the practical ability. As elementary stage for law students to receive comprehensive and systematic education of legal knowledge, the law education of undergraduate course is the appropriate stage to improve the vocational ability of law undergraduates. It can help to improve teaching quality and teaching system and help graduates of law trained by the law education of undergraduate course to adapt to the requirements of working post rapidly. Even though they have not got legal professional qualification, this group can serve as personnel to popularize law in the society. They also need practice thinking of legal profession. Therefore, building interactive mechanism between the law education of undergraduate course and the vocational education of law through various measures is necessary to deepen teaching reform of law education. What's more, it is the strategy to promote the cultivation of legal talents with the ability of legal practice.

\section{REFERENCES}

[1] Hu Wei. The Head of the Reform of Law Education: Accurate Positioning of Educational Objectives [J], Intelligence, 2014, (25):166167

[2] Ma Chenqing. Reasons of Inadequate Vocational Ability of Law of Students in Law Major and Countermeasures (J), Teaching Practice Studying, 2015, (36): 168. 